\title{
Intersectionality and Transformative Reparations: The Case of Colombian Marginal Youths
}

\author{
Elena Butti \\ Centre for Socio-Legal Studies, University of Oxford, Oxford, UK \\ elena.buttiıgmail.com \\ Brianne McGonigle Leyh \\ Utrecht University, Utrecht, The Netherlands \\ B.N.McGonigle@uu.nl
}

\begin{abstract}
The town of San Carlos, highly affected by the Colombian conflict, is often presented as an example of a successful domestic reparations process. Yet not all victims agree with this assessment. A significant number of marginalised adolescents feel that their voices and realities are not reflected in the reparations programme provided by the 2011 Victims' Law. While the programme promises to transform lives, it does little to change the lives of young people at the margins. This article compares and contrasts the legal framework on reparations for underaged victims with insights drawn from ethnographic research with these youths. The situation of these young people signals that transformative reparations are not working as they should. We argue that this failure is due to the mismatch between the conceptualisation of 'vulnerable child-victims' in the text of the law and these youths' nuanced identities. Using intersectionality, we propose an alternative way forward.
\end{abstract}

\section{Keywords}

transitional justice $(\mathrm{TJ})$ - reparations - youth - Colombia - marginalisation intersectionality - transformation 
While the language of transformation and inclusion has recently gained traction in the transitional justice (TJ) field, ${ }^{1}$ we still know too little about whether and how TJ mechanisms can achieve these ambitions in practice. The challenges of realising transformation and inclusion are particularly evident in relation to the lives of the most marginal victims in society. The case of reparations for underaged, marginal victims in Colombia is a case in point. Ethnographic data from long-term research with a group of marginalised male adolescent victims in the town of San Carlos, Colombia, shows us how progressive developments in law and scholarship can fall short in practice. It also provides insights into what changes are needed to better achieve the articulated aims of reparations, including repair but also potentially transformation.

Over the past two decades, two important developments have taken place in the TJ field. First, scholars started to ask whether TJ mechanisms should also contribute to building peace, by transforming the structural causes of conflict, rather than limiting themselves to addressing past conflict-related harms. ${ }^{2}$ Second, specific attention to 'vulnerable' victim groups has taken place, ${ }^{3}$ leading to a more inclusive view of TJ. Specifically, there have been calls for a more 'child-sensitive' approach to $\mathrm{TJ},{ }^{4}$ which implies the recognition that children and adolescents have special rights in $\mathrm{TJ}$ processes, including the right to

1 Although the definition of the term transitional justice (TJ) is contested, the most oftenaccepted definition views $\mathrm{TJ}$ as 'the full range of processes and mechanisms associated with a society's attempts to come to terms with a legacy of large-scale past abuses, in order to ensure accountability, serve justice and achieve reconciliation', United Nations, The Rule of Law and Transitional Justice in Conflict and Post-Conflict Societies (UN Doc S/2004/61), 23 August 2004.

2 See Mariam Salehi, 'Beyond Peace vs. Justice: Assessing Transitional Justice's Impact on Enduring Peace using Qualitative Comparative Analysis', 1 Transitional Justice Review (2016) 96-103; Wendy Lambourne, 'Transitional Justice and Peacebuilding after Mass Violence', 3 International Journal of Transitional Justice (2009) 28-48.

3 This adjective is widely used in both scholarship and practice to refer to socio-economically disadvantaged groups, but there are reservations on the use of this term in general (Mary B. Anderson, 'The Concept of Vulnerability: Beyond the Focus on Vulnerable Groups', 34 International Review of the Red Cross (1994) 327-332), as well as in relation to children specifically (Jo Boyden, 'Children Under Fire: Challenging Assumptions about Children's Resilience', 13 Youth and Environments (2003) 1-29). For this reason, we use it between quotation marks in this article.

4 See ICTJ, Cécile Aptel and Virginie Ladisch, Through a New Lens: A Child-Sensitive Approach to Transitional Justice (ICTJ, New York, 2011). 
participate directly in the design and implementation of TJ mechanisms. ${ }^{5}$ The inclusion of younger generations is also, it is argued, crucial to guarantee the long-term success of efforts to build a lasting peace, and is thus linked to transformative conceptions of TJ. ${ }^{6}$

While these developments have gained resonance at the highest levels, ${ }^{7}$ there is little evidence of how young people's inclusion in TJ mechanisms would work concretely. How can reparations be meaningful to (and transformative for) the youngest in society? In TJ scholarship, the scarce literature dealing with children involves little, if any, empirical research with young people themselves. ${ }^{8}$ In TJ practice, 'there are few examples of mechanisms in which children have participated fully and satisfactorily' ${ }^{9}$ The absence of

5 According to the World Health Organization 'adolescents' include those aged ten to nineteen years, while 'young people' are those aged ten to twenty-four years and 'youth' are fifteen to twenty-four years old. In this article, we use both terms interchangeably to indicate young people in their teens. We only use 'children' when referring to 'children's rights' legislation applicable to those aged $0-18$. Saudamini Siegrist, 'Child Rights and Transitional Justice', in Sharanjeet Parmar et al. (eds.), Children and Transitional Justice: Truth-Telling, Accountability, and Reconciliation (Harvard University Press, Cambridge, 2010) at pp. xix, 10.

6 Robert Ricigliano, Making Peace Last: A Toolbox for Sustainable Peacebuilding (Routledge, Abingdon, 2016) pp. 15-16.

7 Observations by the Special Rapporteur on the promotion of truth, justice, reparation and guarantees of non-recurrence, Mr. Pablo de Greiff, on the conclusion of his recent visit to Sri Lanka, 11 April 2015, http://www.ohchr.org/EN/NewsEvents/Pages/DisplayNews .aspx?NewsID=15820\&, accessed 10 April 2019; Report of the Special Rapporteur on the Promotion of Truth, Justice, Reparation and Guarantees of Non-Recurrence, Pablo de Greiff (A/HRC/30/42) 7 September 2015; Report of the Special Rapporteur on the Promotion of Truth, Justice, Reparation and Guarantees of Non-Recurrence, Pablo de Greiff (A/HRC/21/46) 9 August 2012.

8 The two major publications on the topic are the edited collection Sharanjeet Parmar et al. (eds.), supra note 5; and the UNICEF Innocenti Research Centre (IRC), Working Paper Series (2010). Other publications on the topic were produced by the International Center for Transitional Justice (ICTJ): ICTJ, Aptel and Ladisch, supra note 4; ICTJ, Clara Ramìrez-Barat, Engaging Children and Youth in Transitional Justice Processes: Guidance for Outreach Programs (ICTJ, New York, 2012); IRC \& ICTJ, Children and Truth Commissions (Tipolito Duemila Group, Florence, 2010).

9 Alison Smith, 'Basic Assumptions of Transitional Justice and Children', in Parmar et al. (eds.), supra note 5, at 33. For instance, in their survey of eight truth commissions and reparations programmes, Mazurana and Carlson found that the majority did not expressly recognise grave violations suffered by children, did not recognise children as rights-holders, and did not reach out to them either for input on the design or implementation of the processes or to share the outcomes. See Dyan Mazurana and Khristopher Carlson, 'Reparations as a Means for Recognizing and Addressing Crimes and Grave Rights Violations against Girls and Boys 
young voices in both TJ scholarship and practice is problematic, as it results in adults talking on behalf of, rather than with, children and adolescents concerning their experiences of and input for TJ. Too often, this leads to the development of TJ mechanisms that appear to be perfectly crafted on paper, but that are in fact distant from reality.

Reparations in Colombia are a case in point. The decades-long internal armed conflict, resulting from fighting between guerrillas, paramilitaries, and the national army, has produced over eight million internally displaced people and thousands of victims of killings, kidnappings, sexual violence, landmine injuries and other instances of extreme violence. ${ }^{10}$ Among these, children and adolescents have been disproportionately affected..$^{11}$ In order to provide redress to victims, in 2011 the Colombian government passed the landmark Victims' and Land Restitution Law (Victims' Law), ${ }_{12}^{12}$ which sets out a comprehensive administrative reparations programme. ${ }^{13}$ On paper, the law has a

during Situations of Armed Conflict and under Authoritarian and Dictatorial Regimes', 176, in Ruth Rubio-Marin (ed.), The Gender of Reparations: Unsettling Sexual Hierarchies while Redressing Human Rights Violations (Cambridge University Press, Cambridge, 2005). Exact numbers of officially recognised victims can be found on the Official Victims' Registry, Registro Único de Víctimas, online at rni.unidadvictimas.gov.co/RUV.

11 Despite the fact that underaged victims already constitute around 28 per cent of the victim population (calculated from the data available on the official victims' registry https://rni.unidadvictimas.gov.co/RUV), several sources suggest that the actual number of young victims is highly underreported. See Giraldo Lizcano, John Alexander, and Ana María Jiménez Pava, Garantías y oportunidades para la defensa de la vida: Experiencias de niñas, niños y adolescentes en la ruta de reparación administrativa en Colombia (Benposta, Bogotá, 2015), at p. 33; Informe defensorial.Justicia transicional: Voces y oportunidades para los niños, niñas y adolescentes en la construcción de la paz en Colombia (Defensoría del Pueblo de Colombia, Bogotá, 2014) at p. 48; Impacto del conflicto armado en el estado psicosocial de niños, niñas y adolescentes (Bogotá: Instituto Colombiano de Bienestar Familiar, 2014); Organización Internacional para las Migraciones y UNICEF, The 2015 Report of the Secretary General:Children and Armed Conflict (A/69/926-S/2015/409) 5June 2015, at p. 36, also indicates that children and adolescents are highly affected by 'post-demobilisation armed groups', and, as such, fall outside of many official records on victimisation.

12 Victims and Land Restitution Law 1448 D.O. (2011) [hereinafter Victims' Law].

13 Colombia's armed conflict has officially ended at the end of 2016, when the Colombian Government and the FARC-EP guerrilla have reached a landmark peace agreement. Soon after, negotiations with the second biggest guerrilla ELN started and are currently underway. These developments have convinced many that Colombia has by now entered a 'post-conflict' phase. However, TJ measures and rhetoric have been used in Colombia since 2005, after the achievement of a peace agreement with the paramilitary group Autodefensas Unidas de Colombia, which officially demobilised in 2006. This process lacked transparency and many ex-paramilitaries are said to have rearmed into 'post-demobilisation 
transformative objective and adopts an exemplary 'child-sensitive' approach, ${ }^{14}$ in line with international norms on victims' and children's rights. As we will argue, however, this seemingly well-crafted legal framework does not work for all young victims. This is not only due to poor implementation of the law, but also to conceptual shortcomings in its text. Specifically, the rhetoric of the law simplistically portrays all young victims as 'vulnerable children', rather than appreciating the varied experiences of victimisation and reparations that different groups of young victims may have.

We illustrate this point by comparing and contrasting the text of the Victims' Law with the experiences of a group of marginalised young victims in the town of San Carlos. Our analysis is based on 18 months of ethnographic fieldwork conducted by Elena Butti between March and December 2016, with a followup trip in March-April 2018. ${ }^{15}$ Located in the resource-rich region of Eastern Antioquia, San Carlos was disputed between guerrillas and paramilitaries (supported by the army) for over three decades. This caused the almost complete displacement of the town's inhabitants, about half of which moved to

armed groups', which some consider armed groups to all effects, while others dismiss as simply 'organised crime'. The Clan Úsuga, which is one of the biggest, is also pushing to start peace negotiations with the Government.

14 Law 1448 of 2011 ('Ley de Víctimas y Restitución de Tierras' [Victims' and Land Restitution Law]), Diario Oficial 48096, 10 June 2011.

15 Elena Butti, 'We Are the Nobodies': Youth Violence, Marginality and Social Cleansing in Colombia, DPhil Thesis submitted on 10 January 2019 to the University of Oxford. This research was funded by the UK Economic and Social Research Council (ES/J500112/1), received ethical approval by the University of Oxford (SSD/CUREC1A/14-SSH_C2_15_014), and was carried out within the spirit of the 1975 Helsinki Declaration. Elena Butti spent 9 months living in San Carlos where she conducted ethnographic engagement with a few hundred community members, with some more regularly than with others. While she interacted with the community as a whole, she predominantly focussed on socially excluded adolescents who were prone to engage in organised criminal violence and drug dealing. Most informants were selected through snowball sampling, which is common for studies of violence and illegality or other types of 'hidden' networks. Rather than conducting formal and recorded interviews, which would have been highly inappropriate in this context, the co-author engaged in numerous informal conversations with these youths and extended observation of their activities. These were recorded through field notes on a daily basis. Thus, the quotes presented in this paper should not be read as exact transcriptions but rather as the co-author's best attempt to report what her informants said. Oral informed consent was obtained from all participants in the research (see para. 3, ASA Ethical Guidelines 2011). 
marginal neighbourhoods in the close-by city of Medellín. ${ }^{16}$ Since 2006, however, the weakening of the guerrillas and the implementation of the paramilitary demobilisation process allowed people to start returning - a process that was facilitated by various institutional programmes. ${ }^{17}$ Because of its violent history and its high number of victims, San Carlos was chosen as a pilot case for implementing various components of the reparations programme, and it thus constitutes an excellent case study for our inquiry. ${ }^{18}$

Despite being regarded as a model of 'post conflict' peacebuilding, San Carlos still sees various criminal groups operating in its territory. These groups act as branches of Medellín-based drug-dealing cartels, and routinely use adolescents to carry out low-level tasks such as transporting and selling drugs. It is the experiences of these particular adolescents that this article is concerned with. Most of these young people grew up in Medellín's peripheries and relocated to San Carlos when their families returned following the conflict. Often coming from disintegrated and conflictive families, these young people have typically been expelled or have dropped out of school, and many experience difficulties finding a job. Hence, they spend their days taking and selling drugs, or hanging out in the street, and often end up joining violent criminal groups.

These young people are marginalised in a number of ways: economically, because they are poor; geographically, because they grew up and live in peripheral areas; and socially, because they are heavily stigmatised by their community for 'doing nothing productive with their time', as people in town often say. As we will show, these 'marginalised' youths feel little to no connection with the reparations programme provided by the Victims' Law. We argue that this is because the vulnerability paradigm, according to which underaged victims are portrayed in the law, does not resonate with the way they think of themselves as strong and independent subjects. These youths are thus disillusioned with the reparations programme, which neither captures their voices and realities nor does it offer them realistic life options.

Based on our analysis of the San Carlos case study, we advance a concrete proposal to address these shortcomings in three ways. First, we argue that reparations targeting youths affected by conflict should be offered through flexible,

16 Centro Nacional de Memoria Histórica, San Carlos: Memorias del éxodo en la guerra (2011), at p. 185 .

17 Ibid., 390-397.

18 Juan David Villa Gómez and Alfonso Insuasty Rodríguez, 'Significados en torno a la reparación, la ayuda humanitaria, la indemnización y la restitución en víctimas del conflicto armado en el municipio de San Carlos', 16 El Ágora USB (2016) 165-191, at p. 430. 
intersectional programmes offering more choice than is currently available. ${ }^{19}$ Second, we call for reparations programmes that ensure meaningful input from beneficiaries, rather than sticking to preconceived paradigms as that adopted in the Victims' Law. Third, reparations programmes should address different layers of marginalisation, with the aim to help individuals transform their lives. We maintain that collective transformation may be better pursued by other permanent $\mathrm{TJ}$ processes and development programmes, such as state initiatives aimed at guarantees of non-repetition.

Importantly, our analysis of the Colombian case is also relevant for broader reparations discussions taking place within other domestic and international mechanisms. For instance, our findings inform the design and implementation of reparations and assistance programmes at the Trust Fund for Victims (TFV) at the International Criminal Court (ICC), which are meant to be complementary to a State's obligations to provide remedies to victims. We maintain that understanding the multifaceted identities of youth affected by conflict is crucial if reparations provided by any entity, including the ICC, are to be meaningful to socially marginalised youths.

Methodologically, our analysis shows how a multidisciplinary approach combining legal analysis with long-term ethnographic research can help to render law more meaningful to people on the ground..$^{20}$ On the one hand, this article demonstrates how ethnographic research helps to uncover victims' perceptions, which can lead to questioning the effectiveness of legal texts which appear sound on paper. Ethnography can also help to gain a granular understanding of victimhood, illustrating why and how the law fails some victims more than others. On the other hand, we also maintain that law is not

19 As we further discuss in Section 6, intersectionality is a theory first advanced by feminist scholars of colour, which demands more explicit recognition of the ways in which the convergence of specific social positions and group membership shape experiences and social identity. See Cherríe Moraga and Gloria Anzaldúa (eds.), This Bridge Called My Back: Writings by Radical Women of Color (Persephone, Watertown, 1981); Gloria Hull, Patricia Bell-Scott and Barbara Smith (eds.), All the Women Are White, All the Blacks Are Men, But Some of Us Are Brave: Black Women's Studies (Feminist Press, Old Westbury, NY, 1982); Bonnie Thornton Dill, 'Race, Class and Gender: Prospects for an Inclusive Sisterhood', 9 Feminist Studies (1983) 131-150; Kimberlé Crenshaw, 'Mapping the Margins: Intersectionality, Identity Politics, and Violence against Women of Color', 43 Stanford Law Review (1991) 1241-1299, at p. 1244.

20 See Mark Goodale, Anthropology and Law: A Critical Introduction (New York University Press, New York, 2017); Kimberly Theidon, 'Transitional Subjects: The Disarmament, Demobilization and Reintegration of Former Combatants in Colombia', 1 International Journal of Transitional Justice (2007) 66-90, at p. 74 . 
meaningless: rather, a law that is sensitive to the lived experiences of people can make a huge difference to the lives of the most marginalised.

The structure of this article is as follows: First, we discuss recent developments in the TJ field in relation to more 'transformative' and 'child-sensitive' approaches to reparations. We then turn to our analysis of Colombia's reparations law and its implementation. Following an ethnographic account of the lives of San Carlos' marginalised youths, we discuss their disappointment with what the reparations programme has to offer. Finally, we propose an alternative approach to reparations based on intersectionality, and we advance three concrete proposals on how it could be put into action.

\section{The Emergence of the 'Transformative' Paradigm in TJ}

In recent years, scholars have increasingly reflected on the relationship between $\mathrm{TJ}$ and peacebuilding. ${ }^{21}$ This has led many to call for $\mathrm{TJ}$ to address socio-economic inequalities, which are often pervasive in countries affected by conflict involving mass human rights violations. ${ }^{22}$ Stemming from these concerns, a 'transformative' paradigm emerged within the TJ field. ${ }^{23}$ Advocates of this paradigm argue that $\mathrm{TJ}$ mechanisms should aim to address the structural

21 Lambourne, supra note 2, pp. 28-48; Kora Andrieu, 'Civilizing Peacebuilding: Transitional Justice, Civil Society and the Liberal Paradigm', 41 Security Dialogue (2010) 537-558, at p. 541; Dustin N. Sharp, 'Addressing Economic Violence in Times of Transition: Toward a Positive-Peace Paradigm for Transitional Justice', 35 Fordham International Law Journal (2012) 779-814.

22 Rama Mani, 'Dilemmas of Expanding Transitional Justice, or Forging the Nexus between Transitional Justice and Development', 2 International Journal of Transitional Justice (2008) 253-265; Lisa J. Laplante, 'Transitional Justice and Peace Building: Diagnosing and Addressing the Socioeconomic Roots of Violence through a Human Rights Framework', 2 International Journal of Transitional Justice (2008) 331-355; Rodrigo Uprimny Yepes, 'Transformative Reparations of Massive Gross Human Rights Violations: Between Corrective and Distributive Justice', 27 Netherlands Quarterly of Human Rights (2009) 625-647, at p. 631 .

23 Erin Daly, 'Transformative Justice: Charting a Path to Reconciliation', 12 International Legal Perspectives (2001) 73-183, at p. 73; Paul Gready and Simon Robins, 'From Transitional to Transformative Justice: A New Agenda for Practice', 8 The International Journal of Transitional Justice (2014) 339, at 339-361; Brianne McGonigle Leyh, 'Changing Landscapes in Documentation Efforts: Civil Society Documentation of Serious Human Rights Violations', 33 Utrecht Journal of International and European Law (2017) 44-58, at p. 44. 
conditions of socio-economic inequality that allowed conflict to emerge in the first place. ${ }^{24}$

Among the various TJ mechanisms, reparations have been recognised as the most victim-centred, ${ }^{25}$ with the 'greatest potential for socioeconomic impacts.' ${ }^{26}$ In 2009, Uprimny Yepes put forward the idea of 'transformative reparations'. He argued that because most victims of mass violence are already poor and/or otherwise marginalised before being victimised, for reparations to restore their situation to a status quo ante of poverty and discrimination is both unfair and counterproductive. ${ }^{27}$ Transformative reparations instead aim to 'change the circumstances in which they [victims] lived, and that could have been one of the roots of conflict and that anyway are in themselves unjust'. ${ }^{28}$

However, the idea of transformation within $\mathrm{TJ}$, and of transformative reparations specifically, has been subject to critique. Some have cautioned against the dangers of diluting reparations into development programmes that lack a specific victim-centred focus. ${ }^{29}$ Others point out that the notion of transformation is too vague ${ }^{30}$ and that it dislodges an important focus on reparative justice for individual victims. ${ }^{31}$

Despite these critiques, legal developments at the international and regional level have, to some extent, embraced the transformative paradigm. For instance, the ICC has recognised the idea of the transformative potential of reparations. The Court emphasised that, in addition to the three forms of reparations explicitly mentioned in Article 75 of the Rome Statute - restitution, compensation and rehabilitation - '[o]ther types of reparations, for instance those with a symbolic, preventative or transformative value, may also be

24 David C. Gray, 'Extraordinary Justice', 62 Alabama Law Review (2010) 55-109, at p. 104.

25 Luke Moffett, 'Reparations for 'Guilty Victims': Navigating Complex Identities of VictimPerpetrators in reparations Mechanisms', 10 International Journal of Transitional Justice (2016) 146-167, at p. 148.

26 Gready and Robins, supra note 23, at p. 347.

27 Uprimny Yepes, supra note 22, at 632.

28 Ibid., 641.

29 Pablo De Greiff, 'Justice and Reparations', in Pablo De Greiff (ed.), The Handbook of Reparations (Oxford University Press, Oxford, 2008) at p. 470.

$30 \quad$ Margaret U. Walker, 'Transformative Reparations? A Critical Look at a Current Trend in Thinking about Gender-Just Reparations', 10 International Journal of Transitional Justice (2016) 108-125, at p. 109; see also Brianne McGonigle Leyh and Julie Fraser, 'Transformative Reparations: Changing the Game or More of the Same?', 8(1) Cambridge International Law Journal (2019) 39-59, DOI: https://doi.org/10.4337/cilj.2019.01.02.

Walker, supra note 30,110 . 
appropriate. ${ }^{32}$ In the Lubanga case, the TFV asserted that reparations should contribute to transformation and present an 'opportunity to overcome structural conditions of inequality and exclusion' ${ }^{33}$ This is especially important, the Court argued, for victims who have suffered irreparable harm from international crimes and who are marginalised in their communities. ${ }^{34}$

Regionally, transformative reparations have been called for most notably in the Cotton Field case before the Inter-American Court of Human Rights, which concerned the mishandling of criminal cases related to the systematic disappearance, torture, sexual abuse, and murder of numerous young, working class women in Mexico. In this case, the Court stated that reparations must be designed to address the context of structural discrimination in which the facts of the case occurred 'so that their effect is not only of restitution, but also of rectification'. ${ }^{35}$ The judgement was, however, criticised for failing to apply its own concept of transformative reparations to the concrete reparations awarded by the Court. ${ }^{36}$

These developments in the practice of reparations point to the rising importance of the transformative paradigm in the TJ field. However, full implementation of these calls is scarce, and their practicability and concrete functioning leaves questions to be addressed. Can victims' lives really be transformed through reparations? Can and should reparations programmes aim to transform society as a whole? These are some of the questions this article addresses. First, however, the next section examines a second, parallel development that took place in the TJ field.

32 ICC, The Prosecutor v. Thomas Lubanga Dyilo (Lubanga), Trial Chamber I, Decision establishing the principles and procedures to be applied to reparations ICC-01/04-01/06-2904 (7 August 2012) para. 222; Lubanga, Appeals Chamber, Judgement on the appeals against the 'Decision establishing the principles and procedures to be applied to reparations' of 7 August 2012 with amended order for reparations (Annex A) and public annexes 1 and 2 ICC-01/04-01/06-3129 (3 March 2015) para. 202; ICC, The Prosecutor v Germain Katanga (Katanga), Trial Chamber II, Order for Reparations pursuant to Article 75 of the Statute ICC-01/04-01/07 (24 March 2017) para. 297.

33 Lubanga, Trust Fund for Victims, Observations on Reparations in Response to the Scheduling Order of 14 March 2012 ICC-01/04-01/06-2872 (25 April 2012) para. 72.

34 Ibid., para. 76.

35 Case of González et al. (Cotton Field) v. Mexico, 16 November 2009, Inter-American Court of Human Rights, Series C 205, at para. 450.

36 Ruth Rubio-Marín and Clara Sandoval, 'Engendering the Reparations Jurisprudence of the Inter-American Court of Human Rights: The Promise of the Cotton Field Judgment', 33 Human Rights Quarterly (2011) 1062-1091, at p. 1090. 
A parallel and related development in the TJ field is the increasing concern regarding the better inclusion of marginalised, discriminated, or oppressed groups of victims, such as women, children and ethnic minorities in TJ processes. ${ }^{37}$ This development stems from the recognition that certain social groups are disproportionately and differentially victimised as a result of their social marginalisation, which pre-exists and runs through the conflict. Therefore, TJ should develop specific 'differential approaches' 38 to address these structurally marginalised or 'vulnerable' groups, aimed at better serving their needs and concerns as well as at facilitating their social and political participation more generally. 39

Children have been increasingly recognised as particularly 'vulnerable' victims in TJ processes around the world. ${ }^{40}$ The Convention on the Rights of the Child (CRC) provides the guiding legislation for children and adolescents' inclusion in TJ ${ }^{41}$ Its framework is based on four key principles (non-discrimination; the best interests of the child; the right to life, survival and development; and respect for the views of the child) ${ }^{42}$ which are meant to guide states in their obligation to respect, protect and fulfil the rights of children and adolescents. The CRC recognises the full range of rights - civil, political, economic, social and cultural - together, and requires state parties to place equal importance

37 See Report of the Special Rapporteur on the promotion of truth, justice, reparations and guarantees of non-recurrence, Pablo de Greiff(A/HRC/30/42) 7 September 2015; Report of the Special Rapporteur on the Promotion of Truth, Justice, reparations and Guarantees of Non-Recurrence, Pablo de Greiff(A/HRC/21/46) 9 August 2012.

38 Uprimny Yepes, supra note 22, at p. 645 .

39 ICTJ, Pablo de Greiff, 'Articulating the Links Between Transitional Justice and Development: Justice and Social Integration', in Pablo de Greiff and Roger Duthie (eds.), Transitional Justice and Development: Making Connections (International Center for Transitional Justice, New York, 2009) at p. 33.

40 The volume edited by Parmar et al., supra note 8, features examples from South Africa, Sierra Leone, Liberia, Uganda, and Peru, as well as the international legal arena.

41 Colombia ratified the CRC and incorporated it into Colombia legislation through Law 12 of 1991 ('Por Medio de la Cual se Aprueba la Convención Sobre los Derechos del Niño Adoptada por la Asamblea General de las Naciones Unidas el 20 de noviembre de 1989'), Diario Oficial 39640, 12 January 1991.

42 Committee on the Rights of the Child, The Aims of Education (UN Doc. CRC/GC/2001/1) 17 April 2001, at para. 6 (listing these general principles, which fall under CRC articles 2, 3, 6 and 12). For a discussion of the general principles, see Executive Directive 98-04, 'Guidelines of Human Rights-Based Programming Approach' in Handbook on Legislative Reform: Realizing Child Rights, Vol. 1 (New York: UNICEF, November 2008). 
on all rights. In this sense, the $\mathrm{CRC}$ is in line with recent approaches calling for greater attention on economic, social and cultural rights and with transformative theories within TJ.43

But while adolescents are entitled to special rights in TJ processes, it is also important to consider that adolescents are particularly prone to engage in violence. Quantitative studies on violence around the world, and particularly in Latin America, show that violence is largely perpetrated by young men between their mid-teens and early thirties. ${ }^{44}$ Members of organised criminal groups, which tend to boost levels of violence in post-conflict settings, ${ }^{45}$ typically join these organisations in early adolescence. These young people generally come from poor and marginalised areas that have been largely affected by violence, and are often direct victims of armed conflict themselves. ${ }^{46}$

Besides studies on child-soldiers specifically, ${ }^{47}$ however, the TJ literature has failed to reflect on how to address young victims who also engage in violence. Specifically, young victims who engage in organised urban and periurban violence and crime, which typically increases in post-conflict settings, ${ }^{48}$ are left largely unaddressed. How (if at all) can and should TJ measures contribute to breaking this cycle of violence by better including marginal youths? What does TJ have to offer these youths, who are both 'violent' and 'vulnerable', both 'victims' and 'perpetrators'? These questions need to be answered contextually through direct research with young people, who are 'the greatest

43 See Louise Arbour, 'Economic and Social Justice for Societies in Transition', 40 NYU Journal of Law and Politics (2007) 1-27; Pádraig McAuliffe, 'Structural Causes of Conflict and the Superficiality of Transition', in Claudio Corradetti, Nir Eisikovits and Jack Volpe Rotondi (eds.), Theorizing Transitional Justice (Ashgate Publishing, Farnham, 2015) at p. 94.

Peter Imbusch, Michel Misse, Fernando Carrión, 'Violence Research in Latin America and the Caribbean: A Literature Review', 5 International Journal of Conflict and Violence (2011) $87-154$, at p. 100.

45 Mani, supra note 22, at p. 259.

$46 \quad$ Ibid.

47 Michael A. Corriero, 'Involvement and Protection of Children in Truth and Justice-Seeking Processes: The Special Court for Sierra Leone', 18 New York Law School Journal of Human Rights (2002) 337-36o; see also Theresa S. Betancourt and A Ettien, Transitional Justice and Youth Formerly Associated with Armed Forces and Armed Groups (Florence: UNICEF Innocenti Research Centre, 2010); Mark A. Drumbl, Reimagining Child Soldiers in International Law and Policy (Oxford University Press, Oxford, 2012); Kirsten J. Fisher, Transitional Justice For Child Soldiers: Accountability and Social Reconstruction in Post-Conflict Contexts (Palgrave Macmillan, New York, 2013); Noëlle Quénivet, 'Transitional and Generational Justice: Children Involved in Armed Conflicts', in N. Szablewska and S.D. Bachmann (eds.), Current Issues in Transitional Justice (Springer, London, 2015) pp. 55-81. 
experts in their own lives' ${ }^{\prime 9}$ Below, we examine these questions in the context of Colombia.

\subsection{Child-sensitive Reparations in Colombia}

The Colombian case provides an emblematic illustration of how progressive ideas about transformation and inclusion can fall short in practice. The 2011 Victims' Law is, to date, the oldest and most significant government intervention implementing victims' rights within a TJ framework in Colombia. ${ }^{50}$ The objectives of transformation and inclusion are clearly present in the text of the law.

In terms of transformation, the law explicitly refers to the 'transformative character' of the reparations it aims to provide (Art. 28). It also embraces a broad conceptualisation of 'reparation', which encompasses the five dimensions of compensation, restitution, rehabilitation, satisfaction and guarantees of non-repetition, in line with the international legal framework. ${ }^{51}$ Measures under these dimensions are all accessed on a voluntary basis by individual victims after they have been interviewed by an official of the Victims' Unit. ${ }^{52}$ Moreover, the law emphasises that reparations have the forward-looking aims of 'ensuring non-repetition' and 'achieving a stable peace' (Art. 8).

In terms of inclusion, the law clearly illustrates the intention of including marginalised victims. The reparations programme is set out according to a differential approach (Art. 13), which requires the state to offer special guarantees and protection to those groups considered most 'vulnerable' and at risk of being victimised. According to this principle, such measures should 'contribute to eliminating the discrimination and marginalisation patterns that may have led to victimisation in the first place' (Art. 13). 'Active victims' participation' is recognised as an important requirement to help victims 'overcome their vulnerability' (Art. 14).

49 Alison Clark and June Statham, 'Listening to Young Children: Experts in Their Own Lives', 29 Adoption \& Fostering (2005) 45-56.

5o Phuong Ngoc Pham, Patrick Vinck, Bridget Marchesi, Doug Johnson and Peter J. Dixon, 'Evaluating Transitional Justice: The Role of Multi-Level Mixed Methods Datasets and the Colombia Reparations Program for War Victims', 1 Transitional Justice Review (2016) 6o-94, pp. 66-67.

51 Basic Principles and Guidelines on the Right to a Remedy and Reparations for Victims of Gross Violations of International Human Rights Law and Serious Violations of International Humanitarian Law, UN Doc. A/Res/6o/147 (21 March 2006).

52 The Victims' Unit (Unidad de Víctimas) is the institution set up by the Victims' Law to coordinate the reparations programme. 
Children and adolescents are recognised as one of these 'vulnerable' victim groups in the text of the law, which devotes a whole section exclusively to them (Title VII). This section is grounded in the principle of 'comprehensive protection', which requires the state to recognise, guarantee, prevent the violation of, and re-establish children and adolescents' fundamental rights as enounced in the Childhood and Adolescence Code ${ }^{53}$ (the national transposition of the CRC). ${ }^{54}$ The law also sets out state obligations towards child- and adolescentvictims within the framework of guarantees of non-repetition. ${ }^{55}$ Child-victims also have a specific right to participate in the design and implementation of reparations (Art. 193). ${ }^{56}$

In sum, from a purely text-based analysis, the Victims' Law is a very progressive document, in line with international victims' and children's rights, as well as with recent pushes in TJ scholarship for greater transformation and victims' inclusion. It is one of the few examples of a legal document that has thoroughly incorporated these developments in its text. Indeed, an extensive evaluation report carried out by Harvard University has emphasised its 'admirable vision and comprehensiveness.57 The same report, however, also stresses the huge

53 Art. 7 Law 1098 of 2006, Diario Oficial 46446, 8 November 2006.

54 Art. 8 enounces the principle of best interest, Art. 1 the principle of equality (related to non-discrimination), Arts. 31 and 93 the principle of participation, and Art. 7 the principle of comprehensive protection (related to the right to life, survival and development). Similar principles are also enounced in the Victims' Law itself in relation to victims in general (principle of quality Art. 6 and principle of participation Art. 14) and to child and adolescent victims specifically (principle of comprehensive protection in the title of title viI and the principle of best interest evoked in Art. 191).

55 These include guaranteeing child-soldiers' reintegration (Art. 149 (l)) and preventing further violence against children and adolescents (Art. 149(d) and (s)).

$5^{6}$ One of the practical mechanisms to implement victims' participation is the establishment of 'participation roundtables' (mesas de participación), These are regulated in implementing Decree 4800 of 2011, which establishes that participation of non-organised groups such as underaged victims should be facilitated (Art. 264,), through specific mechanisms (Art. 286 (12)), and that the roundtables should include the discussion of themes that promote the participation of 'vulnerable' groups including children and adolescents (Art. 279(6)). Moreover, Resolución 0388 de 2013 ('Por La cual se adopta el protocolo de participación efectiva de las víctimas del conflicto armado') Diario Oficial 48796, 10 May 2013, establishes that participation should be implemented through a 'differential approach' (Art. 6(h)).

57 Kathryn Sikkink, Phuong N. Pham, Douglas A. Johnson, Peter Dixon, Bridget Marchesi and Patrick Vinck, Evaluation of Integral Reparations Measures in Colombia: Executive Summary (Carr Center for Human Rights Policy, Cambridge, 2015) at p. 2. 
implementation challenges faced by the law, due to poor staffing and lack of adequate funding, ${ }^{58}$ which a variety of other studies have also highlighted. ${ }^{59}$

The implementation of reparations for underaged victims encounters enhanced difficulties, as outlined in the unpublished internal report written by Elena Butti for the Colombian branch of the International Center for Transitional Justice. ${ }^{60}$ The law provides that, instead of immediate monetary compensation, underaged victims who register are assigned a frozen trust fund that gets unfrozen upon their attainment of adulthood. However, at the time of the research, about half-way into the period of validity of the law, the number of child-victims who had been assigned a trust was insignificant. ${ }^{61}$ In terms of rehabilitation, the Victims' Unit set up a series of 'emotional assistance sessions' to make up for the delay in child-specific measures on the part of the Health Ministry, which has the primary responsibility for providing rehabilitation to victims. ${ }^{62}$ However, such meetings had only been implemented in

\section{$58 \quad$ Ibid.}

59 ICTJ, Ana Cristina Portilla Benavides and Cristián Correa, Estudio sobre la implementación del programa de reparación individual en Colombia, March 2015, https://www.ictj .org/sites/default/files/ICTJ-COL-Estudio-reparacion-individual-2015.pdf; Amnesty International, A Land Title is Not Enough: Ensuring Sustainable Land Restitution in Colombia (2014) https://www.amnesty.org/en/documents/AMR23/031/2014/en/, accessed 10 April 2019.

6o Elena Butti, El enfoque diferencial de niñez en la ley de Víctimas: Marco normativo y implementación (Bogotá: International Center for Transitional Justice [internal unpublished report], 2015). The report was based on documents review as well as on based on dozens of interviews with state officials, civil society leaders and other experts working on childsensitive reparations, A summary of the findings can be found in this academic blog post, published by the Oxford Human Rights Hub, http://ohrh.law.ox.ac.uk/the-unrealisticrhetoric-of-childrens-rights-in-colombias-reparations-law/, accessed 10 April 2019.

61 This is based on an interview with Sinthya Rubio Escolar, Victims' Unit official in charge of child-victims reparations within the individual reparations unit, 5 October 2015. Official up-to-date data about the exact number are not available online. However, her assessment is in line with the general critique moved by the follow-up commission on the implementation of the law, which stresses in the conclusions of its latest report the importance of strengthening the implementation of the 'differential approaches' in particular (Comisión de Seguimiento a la Ley de Víctimas y Restitución de Tierras - Ley 1448 de 2011 Periodo 2016-2017, p. 40, www.senado.gov.co/actualidad/item/download/167, accessed 10 April 2019).

62 Interview with Alejandro Cepeda Pérez, coordinator of the Group of Assistance and reparations to Victims within the Office for Social Promotion of the Ministry of Health and Social Protection, 7 October 2015. 
very few, predominantly urban, locations. ${ }^{63}$ In terms of satisfaction measures, the National Historical Memory Centre carried out processes of reconstruction of historical memory with children in four localities within the country, ${ }^{64}$ but no large-scale historical memory exercises were undertaken. Restitution, most notably of land, is a family-based programme with no differentiated component for underaged victims. In terms of guarantees of non-repetition, the only significant concrete measure was the reintegration programme for demobilised children. Finally, child-victims' right to participate in the design and implementation of reparations is regulated through a child and adolescent participation protocol, ${ }^{65}$ which uses a specific methodology foreseeing consultations with 'representative' groups of child-victims. ${ }^{66}$ At the time of the research, however, no instances of child-victim participation had gone further than the pilot stage. ${ }^{67}$

Clearly, the implementation of child-specific reparations provided by the Victims' Law is lagging behind. But the problem is not simply one of poor implementation. Rather, the differential approach to child and adolescent victims foreseen in the law, and the way it is implemented, face serious conceptual shortcomings related to an oversimplification of child-victims' identities. The following sections illustrate this point through ethnographic research with adolescent victims involved in criminal violence in the town of San Carlos.

63 Interview with Camila Jaramillo Arciniegas, Victims' Unit official in charge of the emotional assistance strategy for children within the psychosocial team, 5 October 2015; interview with Sandra Milena Veloza Morales, Victims' Unit official in charge of the emotional assistance strategy for adolescents within the psychosocial team, 5 October 2015. Official up-to-date numbers are not available online.

64 The National Historical Memory Centre (Centro Nacional de Memoria Histórica) is a governmental institution established in 2011 with the aim of building a historical record of the Colombian armed conflict.

65 Resolución oo623 de 2014 ('Por la cual se adopta el Protocolo para la participación de niños, niñas y adolescentes víctimas del conflicto armado colombiano') Diario Oficial 48796, 22 September 2014.

66 'Protocolo para la participación de niños, niñas y adolescentes víctimas de conflicto armado: Anexo técnico - guía metodológica (documento en construcción)' Victims' Unit, 2014. A draft of the guide was only temporarily available on the website of the Victims' Unit.

67 Interview with Ana María Martin Buenaventura and Juan Pablo Rodríguez González, Victims' Unit officials part of the Working Group on Children and Youth within the General Direction, 22 September 2015. 


\subsection{Marginalised Young Victims in San Carlos and Their Experiences of Reparation}

The success or failure of reparations programmes does not only depend on quantifiable figures of implementation, but also, and crucially, on victims' own perceptions of such programmes. ${ }^{68}$ Nowhere is this more evident than in the case of San Carlos, a small Colombian town often labelled as 'the victims' town', ${ }^{69}$ because almost the entire population, including children, qualifies as a victim. ${ }^{70}$ San Carlos is one of the localities where the reparations programme, including its child-specific measures, has progressed the furthest. It is often cited in media and official accounts as a 'model for reparations and restitution,', and is used as a showcase of successful implementation of collective (as well as individual) reparation, ${ }^{72}$ land restitution, ${ }^{73}$ reconciliation, and peacebuilding more broadly. ${ }^{74}$

Yet, as is often the case, reality on the ground is more complex. In the eyes of many adult and young victims alike, the law fails to fulfil its promise to provide integral and transformative reparations. ${ }^{75}$ 'The state talks and talks but never

68 Pamina Firchow and Roger Mac Ginty, 'Reparations and Peacebuilding: Issues and Controversies', 14 Human Rights Review (2013) 231-239, at p. 233.

69 'San Carlos, el pueblo de las víctimas que dijo no', Revista Semana, 5 October 2016, http:// www.semana.com/nacion/articulo/san-carlos-antioquia-el-pueblo-de-las-victimas -que-dijo-no-al-proceso-de-paz-con-las-farc/497878, accessed 10 April 2019.

70 Meeting between the Victims' Unit official responsible for individual reparations in Antioquia and members of the San Carlos municipality, 31 March 2016.

71 'San Carlos, modelo de reparación y restitución', El Colombiano, 8 October 2013, http:// www.elcolombiano.com/historico/san_carlos_modelo_de_reparacion_y_restitucion -GYEC_264299, accessed 10 April 2019.

72 'La unidad para la reparación a las víctimas le cumplió a San Carlos', Alcaldesa Victims' Unit, 30 October 2015, http://www.unidadvictimas.gov.co/es/reparación-colectiva/ "la-unidad-para-la-reparación-las-v\% $3 \mathrm{C}_{3} \% A D c t i m a s-l e-c u m p l i o ́-s a n-c a r l o s "-a l c a l d e s a$, accessed 10 April 2019.

73 'Desde San Carlos inspiran a honduras para iniciar la restitución de tierras', InfOriente Antioquia, 16 October 2017, http://inforiente.info/2017/o9/28/desde-san-carlos-inspiran-a -honduras-para-iniciar-la-restitucion-de-tierras/, accessed 10 April 2019.

74 'San Carlos (Antioquia), un ejemplo de transformación hacia la paz', Canal Institucional, 11 December 2015, https://www.canalinstitucional.tv/noticias/san-carlos-antioquia-un -ejemplo-de-transformacion-hacia-la-paz, accessed 10 April 2019.

75 See also Juan David Villa Gómez and Alfonso Insuasty Rodríguez, 'Significados en torno a la reparación, la ayuda humanitaria, la indemnización y la restitución en víctimas del conflicto armado en el municipio de San Carlos', 16 El Ágora USB (2016) 165-191, pp. 439-440. 
fulfils its promises', locals keep repeating. They ask for quicker delivery of compensation, more psychosocial support, and greater opportunities for participation. Despite these grievances concerning implementation, however, most locals are clearly engaged with the reparations process in some way or another.

But this is not the case for all people in the town of San Carlos. The particular group of adolescent victims the research focussed on - a loose group of predominantly male adolescents who engaged in organised crime and violence - are not at all interested in what the reparations programme has to offer. While all of them qualify as victims, many do not even bother registering for the programme in order to access their reparation. None of them is making plans for how to use the compensation money they are entitled to. The psychosocial assistance offered under rehabilitation is resisted: 'I don't need a psychologist, I am not crazy', they often say. Moreover, they are automatically excluded from the emotional assistance meetings for being out of school. In their eyes, land restitution often translates into unwanted eradication from the exciting city environment to the monotony of a small rural town. They typically do not know about the memorialisation initiatives that fall under satisfaction, and if they do, they consider them 'boring' or 'stupid'. And, despite the fact that some of them have been involved in Medellín gangs associated with organised crime, and are affiliated with criminal groups in San Carlos, the formal demobilisation programmes for young people provided as a measure of guarantees of non-repetition is not accessible to them, because they do not have the required demobilisation certificate. Finally, none of them has been involved in the pilot participation exercises provided by the Victims' Law, which have not even taken place in San Carlos.

In sum, differently from others in town, who blame the state for failing to provide what it promised, these marginal youths are generally uninterested in reparation. In fact, they are dismissive of the whole peace enterprise, and actively counter it through their violent and criminal activities. To understand where these dismissive attitudes and behaviours come from, we must consider the broader context of these youths' lives, as well as their particular experiences of victimisation.

Sustained ethnographic engagement with these youths revealed that one of the most profound impacts the armed conflict has had on their lives is their social stigmatisation. People in town have the tendency to avoid physical proximity with these youths, negatively identifying them as marihuaneros (weedsmokers), viciosos (vicious), drogadictos (drugs-addicts) due to their drugs use, and despising them as people who 'serve no purpose in society', 'are no one in life', and 'are making the town rotten'. This stigmatisation has a direct relationship with the 'social cleansing' practices typically perpetrated by various 
armed groups in the urban environments of both big cities and small towns. ${ }^{76}$ This practice consists in the act of 'cleansing' society from those who make it 'dirty', by killing or displacing those considered social deviants, such as beggars, prostitutes, delinquents and, crucially, drugs-consuming youths, who constitute the largest percentage of the victims of 'social cleansing.' ${ }^{77}$ Armed actors typically engage in such practice in an effort to enhance their local legitimacy and strengthen their territorial control. Indeed, social cleansing is highly legitimised by most locals, who often help the armed group in control identify those to be eliminated because they are 'useless' to society or 'ruin the image' of the town or neighbourhood. ${ }^{78}$

In places where explicit territorial control by armed groups has lowered, like San Carlos, drugs-consuming youths tend to increase in size and visibility. They thus start to be perceived as an urgent social dysfunction and hence become the object of heavy negative signalling. 'We would really need a cleansing', people in town often say, 'look at how dirty the town is getting, it's full of vicious youths'. Instances of social cleansing still take place every once in a while against these youths, perpetrated by the criminal groups that operate in town. Moreover, these youths are subject to heavy signalling by the rest of society on a daily basis. In this sense, the enduring stigmatisation these youths suffer from is a direct effect of the armed conflict. These youths are therefore victimised twice. Not only do they qualify as victims under the Law because they may have been displaced, lost a parent, or are subject to other forms of conflict-related violence. They also continue being victimised to the present day, a result of the stigma attached to them.

But these youths do not passively accept their social marginalisation. Rather, they react to it in complex and ambivalent ways. Being constantly looked at and talked about as marginal leads them to take distance from the rest of society and define their own identity accordingly. As a 17-year-old youth put it:

I stay here, they stay there. It's like staying at the border of things, but not completely separate. You know when you pour oil into water? I am like that. I stay next to society, but I do not mix with it.

\footnotetext{
76 Centro Nacional de Memoria Histórica, Limpieza social: Una violencia mal nombrada (2015) at p. 181. Such practice was mostly perpetrated by paramilitaries, urban gangs, ad hoc cleansing groups and, to a lesser extent, guerrillas.

$77 \quad$ Ibid., 96.

78 Ibid., 49 .
} 
The time and space these young people occupy reflect their alienation from mainstream society. They prefer to hang out in 'marginal spaces' like the peripheries of town, which 'the rest of society' avoids, and in marginal times like evenings or nights, when it is commonly believed that 'good kids stay at home'. These seemingly trivial details about these youths' routines are key to understanding their relationship to the rest of society: one of a mutually recognised, but fundamentally separate, existence. As a 15-year-old explained:

There are two worlds. The first is the one that you see all the time, people working, while the other one is the one which no one sees. But many things happen there. That world happens at night. That's why they say that it's prohibited to go around at night.

The distinction these youths draw between society and themselves is not valuefree. On the 'good versus evil' binary, they inevitably locate themselves within the 'dark', 'low' or 'evil' side, one intrinsically connected to the enactment of violence and crime, and conceptualised in direct opposition to mainstream society's 'high world'. But while belonging to the underworld is embraced at times, at others it is experienced with frustration. As another 15-year-old explained:

We are from the 'low world'. For the government and the police, we are shit. We are nothing for society. They treat us as criminals - even if we haven't done anything, they treat us as criminals.

Feeling stuck, physically and imaginatively, in the marginal realm of the 'low world', these youths are constantly searching for ways to change their situation and gain the social recognition they feel they are being denied. Yet 'standard' pathways that 'good kids' in their community follow, like going to school or finding a job, appear unviable to them. 'I'd like a life in which I was motivated to study, go to a university, have a good job, but it doesn't work', was a 17-year-old's disillusioned statement. Further stating, 'I have always liked evil. I was assigned (asignado) to this life'. Disenchanted with any possibility of change, these youths see becoming 'bad kids' as the only way to achieve recognition and visibility. As this 17-year-old explains:

Your family ignores you. Everyone ignores you. So, you start thinking that behaving badly is the only thing that can make a difference, so that others start seeing you. That's the only thing I want. That others see me, that's why I do bad things. 
The feelings of unfairness emerging from their social marginalisation often lead these youths to engage in violent fantasies. As a 17-year-old said:

When anger takes over, I really don't care what happens to others. I feel so lonely, that seeing others so united makes me think 'I wish I could too...' But I can't, and I never will. Everyone ignores me: my brother ignores me, my dad ignores me, my step-mother ignores me... So what alternative do I have? When you feel alone, everyone humiliates you, and no one shows you love... That's what turns you into un malo (a bad person).

At times, these youths' accounts suggest that the turn to violence is a result of their own choice, their way of responding to feeling marginalised and rejected. In other instances, however, they point at the broader structural factors that push them where they are. As a 17-year-old explained:

You know... killers are not born killers. People become killers not because they want to, but because it is the only option they see. Why doesn't the rest of society ask where killers come from, and why they become like that? But society never asks these questions. It only judges us.

Later in our conversation, this youth further emphasised the link between socio-economic disadvantage and violence:

If we all had the same wealth, we'd never fight. All fighting is for money. The poor becomes a criminal because he wants to be the same as the rich. That's the cause for which criminals fight: equality. If you are starving, with no job, and someone comes to you and gives you two million pesos to kill someone, you just do it. For there to be peace in Colombia there needs be no poverty.

In sum, the situation of these youths illustrates the complex interplay between dynamics of victimisation, marginalisation, and engagement in violence. Legally, as victims and minors, these youths have a right to child-specific reparations under the Victims' Law. Moreover, if reparations are to contribute to building peace, youths who are prone to turn violent are also those whom reparations need to address most urgently. Yet, as the next section shows, the law fails to appreciate these youths' nuanced identities, as well as their particular experiences of victimisation, and it therefore fails to provide interventions that are meaningful to them. 


\subsection{One-Variable Approach vs Intersectional Approaches to Understanding Victims' Identity}

The one-variable approach adopted by the Victims' Law, which establishes clusters of 'vulnerable' victims defined around one variable, like 'women', 'children', or 'ethnic minorities', leads to the creation of ad hoc interventions designed around essentialised images of victims. ${ }^{79}$ The risk is for complex individual narratives to be 'reduced to oppressive stereotypes with stock stories' $^{80}$ This single-ground focus fails to recognise the complex ways in which stigma is attached to individuals whose identity lies at the intersection of these grounds. In our case, specifically, the emphasis on the ideas of rehabilitation, vulnerability, innocence, and protection generate an oversimplified and unidimensional image of young victims. This image starkly contrasts with the much more complex identity of the marginal youths this article describes, for whom engagement in violence and display of strength are central to identity construction.

The marginalised youths at the centre of this study do not see themselves as 'vulnerable' or 'traumatised'. As such, they do not want to be psychologically treated for trauma, nor are they interested in taking part in memory exercises: they want jobs, education, and social recognition. However, the social stigma attached to them hinders their access to such opportunities. And while such stigma is intrinsically connected to the social cleansing practices perpetrated

79 Critical victimologists have defined the ideal victim as 'a person or category of individuals, who, when hit by crime, most readily are given the complete and legitimate status of being a victim' (Nils Christie, 'The Ideal Victim', in Ezzat A. Fattah (ed.), From Crime Policy to Victim Policy (Macmillan, London, 1986) at p. 18). Critical victimologists have emphasised the tendency to construct an image of a 'deserving victim' (Simon Green, 'Crime, Victimisation and Vulnerability', in Sandra Walklate (ed.), Handbook of Victims and Victimology (Willan, Cullompton 2007), at p. 91) in whose name victim policies are designed and justified (Basia Spalek, Crime Victims: Theory, Policy and Practice (Palgrave Macmillan, Basingstoke, 2006)). In transitional contexts, it has been noted that the ideal victim is constructed as 'a faultless innocent' criminalised by 'a wicked perpetrator' (Kieran McEvoy and Kirsten McConnachie, 'Victims and Transitional Justice: Voice, Agency and Blame', 22 Social \& Legal Studies (2013) 489-513, at p. 493). For a more specific discussion of essentialised identities in the Colombian Victims' Law, see also Sanne Weber, 'From Victims and Mothers to Citizens: Gender-Just Transformative Reparations and the Need for Public and Private Transitions', 12 International Journal of Transitional Justice (2018) 88-107; and Tatiana Sanchez Parra, 'The Hollow Shell: Children Born of War and the Realities of the Armed Conflict in Colombia', 12 International Journal of Transitional Justice (2018) 45-63.

8o Geneva Brown, 'Ain't I a Victim? The Intersectionality of Race, Class, and Gender in Domestic Violence and the Courtroom', 19 Cardozo Journal of Law \& Gender (2012) 147-183, at p. 151 . 
by conflict-related armed actors during the conflict, it is not explicitly recognised as a form of victimisation by the Victims' Law. The law thus fails to address the specific ways in which these youths have been victimised by the conflict. This is why these young people feel excluded - and choose to be excluded - from the reparations programme they are in principle entitled to.

The ethnographic case presented here shows that the Victims' Law does not fail all victims in the same way. The programme offered by the law is only meaningful to (and therefore accessed by) some youths, but not others, thus perpetuating what McEvoy and McConnachie have referred to as a hierarchy of victimhood'.81 As Ní Aoláin and Rooney put it, 'the presumed benefits of transition do not apply equally to all'.82 The marginalised youths at the centre of this study do not see their identity and specific forms of victimisation recognised in the law at all. By failing to appreciate these youths' multifaceted identities, and the specific impacts the armed conflict had on them, the differential approach foreseen by the Victims' Law results in interventions that are ineffective at best, and furthering exclusion at worst.

An alternative way forward is, however, possible. We argue that a stronger incorporation of intersectional theories into approaches to reparations could significantly improve the effectiveness of the reparations programme and how it is perceived by marginalised people such as these youths. Intersectionality refers to 'the interactivity of social identity structures such as race, class, and gender in fostering life experiences, especially experiences of privilege and oppression'.83 It implies that identity is always a combination of various variables, and cannot be reduced to a single one. As it has expanded, newer definitions extend beyond race, class, and gender to include age, caste, citizenship, education, socio-economic status, and other variables. ${ }^{84}$

Scholars in the TJ field have started to advocate for intersectional approaches to understanding victims' identities in transitional societies. ${ }^{85}$ Recently,

81 McEvoy and McConnachie, supra note 79, pp. 489-512.

82 Fionnuala Ní Aoláin and Eilish Rooney, 'Underenforcement and Intersectionality: Gendered Aspects of Transition for Women', I International Journal of Transitional Justice (2007) $338-354$, at p. 348.

83 Ahir Gopaldas, 'Intersectionality 101', 32 Journal of Public Policy and Marketing (2013) 90-94, at p. 90.

$84 \quad$ Ibid., 91.

85 See Fionnuala Ní Aoláin, 'Advancing Feminist Positioning in the Field of Transitional Justice', 6 International Journal of Transitional Justice (2012) 205-228, at p. 209; Eilish Rooney, 'Engendering Transitional Justice: Questions of Absence and Silence', 3 International Journal of Law in Context (2007) 93-107; Ní Aoláin and Rooney, supra note 82, at p. 338. See Rubio-Marín, supra note 9; Rubio-Marín and Sandoval, supra note 36, pp. 1062-1091. 
human rights bodies have also begun to adopt more intersectional approaches to address issues of discrimination, stigmatisation, and marginalisation. ${ }^{86}$ They have started examining the interconnection between social identity structures and adopting a structural view of discrimination. For instance, the CEDAW Committee, ${ }^{87}$ the CERD Committee, ${ }^{88}$ the CRC Committee, ${ }^{89}$ and other human rights law treaty bodies, ${ }^{90}$ have begun embracing a more intersectional approach. In the Joint General Recommendation/General Comment on harmful practices, ${ }^{91}$ the CEDAW and CRC Committees note how multiple and intersecting forms of discrimination, referencing, amongst other things, sex, gender, and age, often involve violence and cause harm and suffering to the individuals involved..$^{92}$

Like international human rights treaty bodies, regional human rights documents and bodies have also addressed, to varying degrees, issues of

86 Ivona Truscan and Joanna Bourke-Martignoni, 'International Human Rights Law and Intersectional Discrimination', 16 The Equal Rights Review (2016) 103-131, pp. 111-131, examining the CEDAW Committee, CERD Committee, CRC Committee, CRDP Committee and CESCR Committee; Lorena P. A. Sosa, 'Inter-American Case Law on Femicide: Obscuring Intersections?', 35 Netherlands Quarterly of Human Rights (2017) 85-103, pp. 98-102.

87 CEDAW Committee, General Recommendation No. 28 on the Core Obligations of States Parties under Article 2 of the Convention on the Elimination of All Forms of Discrimination Against Women (UN Doc. C/2010/47/GC.2) 19 October, 2010, at p. 18. See also CEDAW Committee, Summary of the Findings Concerning the Philippines under Article 8 of the Optional Protocol to the Convention on the Elimination of All Forms of Discrimination Against Women, (UN Doc. CEDAw/C/OP.8/PhL/1) 22 April 2015; CEDAW, Cecilia Kell v. Canada, Communication No. 19/2008 (UN Doc. CEDAW/C/51/D/19/2008) 26 April 2012; CEDAW, $R P B$ v. the Philippines, Communication No. 34/2011 (UN Doc. CEDAW/C/57/D/34/2011) 12 March 2014; CEDAw, E.S. and S.C. v. Tanzania, Communication No. 48/2013 (UN Doc. CEDAW/C/6o/D/48/2013) 13 April 2015.

88 CERD Committee, General Recommendation No. 25, Gender Related Dimensions of Racial Discrimination (U.N. Doc. A/55/18) 20 March 2000, para. 1.

89 CrC Committee, General Comment No. 9, The Rights of Children with Disabilities (UN Doc. CRC/C/GC/9) 27 February 2007, at para. 8.

90 In addition to the bodies discussed above, the CESCR Committee has stated in General Comment No. 22 On the Right to Sexual and Reproductive Health (UN Doc. E/C.12/GC/22) 4 March 2016, at para. 2: '[For] certain individuals and population groups that experience multiple and intersecting forms of discrimination that exacerbate exclusion in both law and practice, $[\ldots]$ the full enjoyment of the right to sexual and reproductive health is further restricted.

91 CEDAW Committee and the CRC Committee, Joint General Recommendation No. 31/General Comment No. 18 on Harmful Practices (UN Doc. CEDAW/C/GC/31-CRC/C/GC/18) 14 November 2014.

92 See also CRPD Committee, General Comment No. 3 (2016) On Women and Girls With Disabilities (CRPD/C/GC/3) 25 November 2016, para. 3 . 
intersectionality. For instance, Art. 9 of the Inter-American Convention on the Prevention, Punishment and Eradication of Violence against Women, calls on States Parties to take special account of the vulnerability of women to violence by reason of their race, ethnic background, or status as a migrant, refugee or displaced person. ${ }^{93}$ This article further recognises that consideration should also be had for women who are disabled, minors, disadvantaged socioeconomically, affected by armed conflict, or deprived of their freedom. In terms of jurisprudence, the Inter-American Commission, and, to a lesser extent, the Inter-American Court, are sometimes adopting intersectional perspectives when reviewing discrimination or violations under the American Convention of Human Rights. ${ }^{94}$ More specifically, the Commission and the Court are delving into questions about how women affected by poverty are often more susceptible to acts of discrimination and violence by state agents. They are also discussing the enhanced duty to protect female children, highlighting the 'vulnerable' position of both groups. ${ }^{95}$ Importantly, the case law from the Court and other bodies signals that formalised processes are, to some degree, ${ }^{96}$ able to discuss socio-structural issues concerning 'vulnerable' sub-groups. ${ }^{97}$

While therearecallsformore concretestandards related to intersectionality, ${ }^{98}$ all in all intersectional theories have helped both international and regional

931994 Inter-American Convention on the Prevention, Punishment, and Eradication of Violence against Women (Convention of Belem do Para) ILM 33 (1994) 1534.

94 Sosa, supra note 86, pp. 93-102; for a discussion of this issue by the Inter-American Commission, see Inter-American Commission on Human Rights, Access to Justice for Women Victims of Violence in the Americas (oEA/Ser.LN/VII., doc. 68) 20 January 2007; InterAmerican Commission on Human Rights, Violence and Discrimination Against Women in the Armed Conflict in Colombia (oEA/Ser.LJVIII. 124, doc. 67) 18 October 2006; Inter-American Commission on Human Rights, Report on the Rights of Women in Haiti to Be Free from Violence and Discrimination (oEA/Ser.L./VII, doc. 64) 10 March 2009; Case of González et al. (Cotton Field) v. Mexico, supra note 35 (remarking on intersectional elements but not fully addressing the intersectional dimension).

95 Case of González et al. (Cotton Field) v. Mexico, ibid., at para. 403.

96 Sosa, supra note 86, at p. 93-102.

97 Mónica Feria Tinta, The Landmark Rulings of the Inter-American Court of Human Rights on the Rights of the Child: Protecting the Most Vulnerable at the Edge (Martinus Nijhoff Publishers, Leiden, 2008) at p. 11; see also Villagran-Morales et al. ('Street Children') v. Guatemala, 19 November 1999, Inter-American Court of Human Rights, Series C No. 63; Sawhoyamaxa Indigenous Community of the Enxet People v. Paraguay, 29 March 2006, Inter-American Court of Human Rights, Series C No 146).

98 See Rosa M. Celorio, 'The Wights of Women in the Inter-American System of Human Rights: Current Opportunities and Challenges in Standard-Setting', 65 University of Miami Law Review (2011) 819-866, at p. 858. 
human rights bodies to start addressing complex social identity constructions resulting in marginalisation. While so far intersectionality has mainly been used to address the interaction between victimisation and gender (typically with a focus on women), using it as a lens to understand the experiences of young male victims could be very fruitful. This is an approach that national reparations programmes, such as the Colombian one, can fruitfully learn from and push forward. In the following section, we set out three concrete proposals on how this could be done.

A more intersectional approach to reparations can add complexity and nuance to the crystallised child-victim image, moving beyond one-dimensional views of victims and thus resulting in more inclusive and transformative programmes. We believe this approach is not only relevant for young victims, but also to shape reparations programmes that may be more meaningful to any victim, each of which has their specific needs and 'vulnerabilities'. Concretely, our argument advances three core points:

1) Flexible, intersectional programmes with more choice: While intersectionality demands the recognition of each individual's unique, specific intersectional identity, designing separate programmes for the virtually infinite number of victim identities would be highly unpractical. Rather than separate pre-set programmes for 'vulnerable' victims' groups categorised according to single-ground perspectives, a realistic application of an intersectional lens would require highly flexible programmes, that avoid grouping victims in homogeneous and exclusionary categories, but rather give more choice to users on how to best use the resources the state makes available to them. This does not necessarily require more resources but a better, more flexible allocation of the existing ones. For example, had San Carlos' marginalised youths been given a real possibility to choose what they wanted from the reparations programme, they would have emphasised the importance of tackling the stigmatisation and socio-economic disadvantage that so profoundly affect their lives. These dimensions could then have been better incorporated into the reparations programme, for example by focusing less on backward-looking psychological and commemorative work, and more on forward-looking educational and job opportunities.

2) Ensuring meaningful input from beneficiaries: Flexible programmes can only work with the meaningful input of beneficiaries. Ensuring victims' 
participation in the design and implementation of reparations is key. It can foster a sense of belonging to the programme, restore some trust in the state, and make reparations substantively more relevant to victims themselves. Yet inclusive participation demands spaces where the voices, views, and concerns of all those affected can be heard, ${ }^{99}$ even in cases where they may contrast with other dominant narratives. The programme to facilitate children's and adolescents' participation in the design and implementation of the Victims' Law proposed a series of formalised activities that could only be implemented in spaces like schools or educational centres. ${ }^{100}$ Ensuring the participation of marginalised youths in this kind of initiatives is particularly challenging, for these youths actively reject involvement in formalised activities or institutional spaces. Out-of-school initiatives to facilitate the participation of such youths should be undertaken in marginal spaces like urban peripheries, and marginal times like evenings and nights, which these youths inhabit. Non-judgmental attitudes should be adopted by the officials carrying out such initiatives, and a genuine willingness to talk to these youths in their own terms is essential. Inevitably, in certain cases, direct youth participation in the design of reparations programmes may not be the most suitable way forward. Sometimes, the input of people who know the reality of marginalised groups well, such as community workers or qualitative researchers, might provide useful insight to shape reparations.

3) Addressing different layers of marginalisation: An intersectional approach further demands a recognition of the different layers of marginalisation affecting individuals, and specific initiatives to address each of them. In the case of San Carlos' marginalised youths, this means recognising the circular relationship between victimisation, marginalisation, and engagement in violence. Youth engagement in violence should not be a reason to consider these youths as less worthy victims. Rather, they should be regarded as victims whose situations need to be tackled urgently. The ethnographic material we presented shows that youth violence emerges at the intersection of two different layers of marginalisation: the social stigma attached to them and the socio-economic disadvantage that affects the contexts in which they live. Meaningful reparations require

99 See Pablo de Greiff, Report of the Special Rapporteur on the Promotion of Truth, Justice, reparations and Guarantees of Non-Recurrence (UN Doc. A/HRc/21/46) 9 August 2012, pp. 54-57; Juan Mendez, 'Victims as Protagonists in Transitional Justice', 10 International Journal of Transitional Justice (2016) $1-5$.

Victims' Unit, supra note 66. 
tackling both of these dimensions. For instance, in Medellín there are a series of initiatives that 'professionalise' these youths' passion for rap music, hip hop, and other elements of 'underground' culture in ways that create a source of revenue for them. These initiatives show the youths that tastes and skills for which they are normally stigmatised can become reasons of social approval and inclusion. They also show the rest of society that such artistic expressions are not necessarily associated with violence, but can also be ways to promote a culture of peace and citizenship. Finally, they can provide a small source of revenue which may help lowering these youths' socio-economic disadvantage - while they cannot and should not replace the much-needed structural interventions to create viable job opportunities for Colombia's unskilled youths more generally. ${ }^{101}$

Our assessment is that state-led reparations, on their own, should not aim at achieving full societal transformation. The difficulties identified in the implementation of Colombia's reparations law show the huge challenges encountered even when reparations 'simply' limit themselves to trying to fulfil individual victims' rights. Other components of TJ, like broader institutional reform, or non-TJ interventions, like development programmes, are certainly more suited to work towards the transformation of society as a whole. Only when combined with larger, permanent processes can more radical, transformative changes take shape in society.

We do maintain, however, that reparations could aim to provide some degree of transformation of the individual lives of victims. In many post-conflict contexts, access to employment can literally transform a marginal youth's life, and prevent him or her from pursuing a violent path. Moreover, if reparations manage to facilitate the 'participation of citizens who were previously excluded and marginalised,',102 they can also, according to de Greiff, help to promote social integration, thus serving the broader interests of development. ${ }^{103}$ In this sense, reparations can involve a humble, but concrete, transformational element not only at the individual, but also at the societal level.

This point is also relevant for other domestic and international contexts addressing reparations for serious crimes, like the ICc. Especially because the

101 See Recommendations of the Committee of Economic, Social and Cultural Rights, Concluding Observations on the Sixth Periodic Report of Colombia (E/C.12/COL/CO/6) 19 October 2017, at para. 29 .

102 ICTJ, Pablo de Greiff, 'Articulating the Links between Transitional Justice and Development: Justice and Social Integration', in de Greiff and Duthie, supra note 39, at p. 62.

103 Ibid., 33 . 
reparations and assistance programmes from the ICC are not part of state-led processes, the emphasis should not be on societal transformations as such. Yet, flexible, inclusive, and intersectional polices should be pursued. More generally, only when reparations for young people can be flexible, provide a space for meaningful input, and address different layers of marginalisation, will we begin to see true individual transformations take shape that can potentially contribute to ending cycles of violence.

\section{$5 \quad$ Conclusion}

The case of child-specific reparations within Colombia's Victims' Law illustrates the complexities that emerge when law encounters the social world. While the law incorporates international victims' and children's rights standards, and reflects recent developments in the TJ literature and international jurisprudence more broadly, it falls short in practice. Ethnographic research with adolescents in the town of San Carlos, national showcase of successful reparations and peacebuilding, shows that a significant number of young people do not perceive such reparations as meaningful. The social marginalisation these youths are subject to within their community, together with the lack of opportunities in the socio-economically disadvantaged contexts in which they live, lead them to turn to organised violence and crime, thus contributing to threatening Colombia's fragile peace.

These youths' experiences prompt us to advance a conceptual (rather than merely operational) critique to the reparations law. There are gaps and oversimplifications in how the law conceptualises young victims' identities and the harm they suffered and continue to suffer as a result of the conflict. Because of this, the reparations programme is accessible and meaningful to some youths, but not to others. In this way, the law ends up perpetuating hierarchies among more and less deserving victims, and hindering, rather than contributing to, peace.

More broadly, our discussion illustrates the divide between discourse and practice in the TJ field. Over the past ten years, TJ scholarship has increasingly advocated for greater intersectional and transformative justice theories to be realised in TJ programming. In practice, both international and regional human rights bodies are starting to use intersectional and transformative approaches when addressing human rights violations. However, as the case of Colombia's Victims' Law illustrates, the incorporation of international legal standards and progressive $\mathrm{TJ}$ theories in the legal texts establishing $\mathrm{TJ}$ mechanisms is not enough to ensure their genuine fulfilment. For instance, in this 
case, the CRC framework is in line with transformative and inclusive TJ agendas, but the way it is incorporated and implemented in the Victims' Law fails to live up to the spirit of the Convention.

A more intersectional approach to conceptualising victimhood can provide an alternative way forward. We recommend that reparations programmes be designed to i) be flexible and intersectional in that they offer more choice for each individual victim; ii) be more inclusive with greater direct and indirect participation efforts; and iii) include ways to address the different layers of marginalisation that may affect an individual's life. We provide examples on the concrete shape these proposals could take to become meaningful for marginalised youths in Colombia, but we maintain that such flexible and intersectional approach is suitable to provide more meaningful reparations for all individual victims, not only to marginalised youths. While asking reparations programmes to transform the structural conditions of socio-economic disadvantage of the whole of society is unrealistic, pursuing transformation of individual victims' lives is achievable. These lessons are important not only for Colombia but also for other domestic and international contexts addressing reparations for serious crimes.

On a final, methodological note, our analysis illustrates the usefulness of multidisciplinary approaches within TJ. In recent years, academics from the empirical and social sciences have started to focus on the 'lived' dimension of $\mathrm{TJ},{ }^{104}$ which has led some to dismiss legal analysis. In many contexts, however, law matters: contextually-informed law can be fundamental in shaping policy and thus the lives of 'real' people. Our case study makes this point, while also emphasising how crucial it is for law to stay connected with, and facilitate the solution of, 'real world' problems, rather than covering them up with 'law talk. ${ }^{105}$ We neither dismiss law as totally irrelevant to people's daily needs and concerns, nor portray it as a panacea for all problems. Rather, we maintain that contextually-informed law-making can be a fundamental factor in facilitating better transitions and thus help build sustainable peace.

104 See Alexander L. Hinton (ed.), Transitional Justice: Global Mechanisms and Local Realities after Genocide and Mass Violence (Rutgers University Press, New Brunswick, 2010); Rosalind Shaw, Lars Waldorf and Pierre Hazan (eds.), Localizing Transitional Justice: Interventions and Priorities after Mass Violence (Stanford University Press, Stanford, 2010).

105 Kieran McEvoy, 'Beyond Legalism: Towards a Thicker Understanding of Transitional Justice', Journal of Law and Society 34 (2007) 411-440, at p. 419. 